\title{
Peningkatan keterampilan basic photography dengan smartphone dan penyusunan laporan keuangan UMKM
}

Zubaidi Indra $^{1}$, Yenni Agustina ${ }^{2}$, Kiagus Andi ${ }^{3}$

Fakultas Ekonomi dan Bisnis, Universitas Lampung, Bandar Lampung ${ }^{1,2,3}$

ahmad.zubaidi@feb.unila.ac.id ${ }^{1}$, yenni.agustina@feb.unila.ac.id ${ }^{2}$, kiagus.andi@feb.unila.ac.id ${ }^{3}$

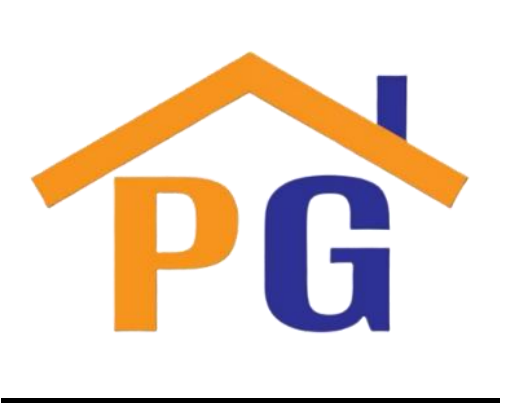

Riwayat Artikel

Diterima pada 1 September 2020

Direvisi pada 24 November 2020

Disetujui pada 22 Desember 2020

\begin{abstract}
Technology and financial reports have a vital role in business life. Technology can help MSME players in marketing their products to areas that are difficult to reach for them. One form of technology that has an important role is cell phones. This tool, which is better known as a communication tool, can also act as an attractive image-producing tool that can support MSME players in marketing their products. However, not all MSMEs can use this tool optimally due to the lack of knowledge and skills in photography. Meanwhile, financial reports for stakeholders are no less critical for the continuity of MSME businesses, especially in obtaining financial assistance from the government. Kelurahan Tanjung Raya, especially RT 015 , is out of the population working as a business actor. However, the development of MSMEs was not so fast due to their lack of knowledge in marketing goods and preparing financial reports. Based on this phenomenon, the team conducted a Community Service attended by 10 MSME actors. This service activity was carried out at the Bunda Delima Akper for 1 day, considering it was in a covid 19 situation. At the time of this activity, the participants were so enthusiastic about taking part in training and practicing photography so that this activity could provide positive values for the participants.
\end{abstract}

Keywords: Handphone, Financial report, MSME

\section{Pendahuluan}

\section{Analisis situasi}

UMKM saat ini merupakan salah satu kekuatan pendorong terdepan dalam pembangunan ekonomi. Hal disebabkan karena UMKM mampu untuk menyerap tenaga kerja sehingga dapat mengurangi tingkat pengangguran. UMKM juga mampu menciptakan lapangan pekerjaan lebih cepat dibandingkan sektor usaha lainnya, dan juga cukup terdiversifikasi dan memberikan kontribusi penting dalam ekspor dan perdagangan, sehingga UMKM merupakan aspek penting dalam pembangunan ekonomi yang kompetitif (www.worldbank.org). Kemampuan UMKM dalam menampung jumlah pekerja dibuktikan dengan data statistik dari BPS yang menyatakan bahwa penyerapan jumlah tenaga kerja menurut skala usaha pada tahun 2016, yakni sebesar 53,64 juta orang atau $76,28 \%$ bekerja pada usaha mikro kecil menengah, dan 16,67 juta orang atau $23,71 \%$ bekerja pada usaha besar. (www.bps.go.id). Namun, dibalik keunggulan yang dimiliki UMKM terdapat juga kelemahan yang menjadi penghambat kemajuan perkembangan UMKM antara lain:

\section{Modal}

2. Manajemen pemasaran yang baik

3. Teknologi yang mampu mendukung kemajuan usaha

4. SDM yang mempuni

Sehingga diperlukan upaya dari berbagai pihak baik dari pemerintah maupun akademisi untuk mengatasi hal tersebut.

\section{Permasalahan mitra}

Kecamatan kedamaian merupakan salah satu kecamatan yang terletak di Kota Bandar Lampung. Kecamatan ini menaungi kelurahan antara lain yaitu kelurahan Tanjung Raya dan Tanjung Gading. Pada umumnya pelaku UMKM di dua kelurahan ini yaitu bergerak di bidang usaha mikro seperti warung sederhana dan toko kue sederhana. Berikut ini akan ditampilkan data perkembangan 
UMKM di kecamatan Kedamaian.

Tabel 1. Data UMKM per kecamatan di kota Bandar Lampung 2014

\begin{tabular}{|c|c|c|c|c|c|}
\hline No & KECAMATAN & $\begin{array}{c}\text { Usaha Mikro } \\
\text { (0 s/d Rp. } \\
50 \mathrm{jt})\end{array}$ & $\begin{array}{l}\text { Usaha Kecil } \\
\text { (>Rp.50jt } \\
\text { s/d 500jt }\end{array}$ & $\begin{array}{c}\text { Usaha Menengah } \\
\text { ( }>\text { Rp 500jt } \\
\text { s/d Rp 2.500jt }\end{array}$ & $\begin{array}{c}\text { Jumlah } \\
\text { UMKM }\end{array}$ \\
\hline 1 & Tanjung Karang Pusat & 1.024 & 850 & 327 & 2.201 \\
\hline 2 & Tanjung Karang Timur & 880 & 691 & 243 & 1.814 \\
\hline 3 & Tanjung Karang Barat & 851 & 765 & 230 & 1.846 \\
\hline 4 & Kedaton & 980 & 809 & 297 & 2.086 \\
\hline 5 & Rajabasa & 1.000 & 686 & 263 & 1.949 \\
\hline 6 & Tanjung Senang & 1.009 & 770 & 320 & 2.099 \\
\hline 7 & Sukarame & 1.016 & 894 & 262 & 2.172 \\
\hline 8 & Sukabumi & 966 & 650 & 309 & 1.925 \\
\hline 9 & Panjang & 1.026 & 900 & 260 & 2.186 \\
\hline 10 & Teluk Betung Selatan & 1.005 & 775 & 228 & 2.008 \\
\hline 11 & Teluk Betung Barat & 984 & 636 & 218 & 1.838 \\
\hline 12 & Teluk Betung Selatan & 974 & 620 & 285 & 1.879 \\
\hline 13 & Kemiling & 1.016 & 812 & 224 & 2.052 \\
\hline 14 & Teluk Betung Timur & 958 & 773 & 297 & 2.028 \\
\hline 15 & Enggal & 927 & 920 & 235 & 2.082 \\
\hline 16 & Bumi Waras & 987 & 662 & 268 & 1.917 \\
\hline 17 & Way Halim & 998 & 650 & 258 & 1.906 \\
\hline 18 & Kedamaian & 988 & 716 & 278 & 1.982 \\
\hline 19 & Labuhan Ratu & 986 & 806 & 254 & 2.046 \\
\hline 20 & Langkapura & 984 & 705 & 255 & 1.944 \\
\hline & Jumlah & 19.559 & 15.090 & 5.311 & 39.960 \\
\hline
\end{tabular}

Sumber: Lakip Diskoperindag Kota Bandar Lampung, 2014.

Tabel 2. Data UMKM Kota Bandar Lampung

DATA UMKM KOTA BANDAR LAMPUNG

BULAN DESEMBER PERKECAMATAN TAHUN 2018

\begin{tabular}{|c|c|c|c|c|c|}
\hline No & Kecamatan & $\begin{array}{c}\text { Usaha } \\
\text { Mikro } \\
\text { (O s/d } \\
\text { Rp.50.000. } \\
\text { O00) }\end{array}$ & $\begin{array}{c}\text { Usaha Kecil } \\
\text { (>Rp.50.000. } \\
\text { O00 s/d } \\
\text { Rp.500.000. } \\
\text { O00) }\end{array}$ & $\begin{array}{c}\text { Usaha } \\
\text { Menengah } \\
\text { (>Rp.500.000.0 } \\
\text { 00 s/d } \\
\text { Rp.10.000.000 } \\
\text {.000) }\end{array}$ & $\begin{array}{c}\text { Jumlah } \\
\text { UMKM } \\
\text { (unit) }\end{array}$ \\
\hline 1. & Tanjung Karang Pusat & 1.760 & 890 & 342 & 2.992 \\
\hline 2. & Tanjung Karang Timur & 1.199 & 709 & 245 & 2.153 \\
\hline 3. & Tanjung Karang Barat & 994 & 776 & 238 & 2.008 \\
\hline 4. & Kedaton & 1.172 & 836 & 309 & 2.317 \\
\hline 5. & Rajabasa & 1.369 & 714 & 270 & 2.358 \\
\hline 6. & Tanjung Senang & 1.186 & 784 & 325 & 2.295 \\
\hline 7. & Sukarame & 1.418 & 912 & 267 & 2.597 \\
\hline 8. & Sukabumi & 1.180 & 672 & 315 & 2.167 \\
\hline 9. & Panjang & 1.191 & 917 & 268 & 2.376 \\
\hline 10. & Teluk Betung Selatan & 1.309 & 795 & 236 & 2.340 \\
\hline 11. & Teluk Betung Barat & 1.316 & 653 & 220 & 2.189 \\
\hline 12. & Teluk Betung Utara & 1.166 & 635 & 291 & 2.092 \\
\hline 13. & Kemiling & 1.670 & 846 & 232 & 2.746 \\
\hline 14. & Teluk Betung Timur & 1.098 & 788 & 301 & 2.187 \\
\hline 15. & Enggal & 1.249 & 942 & 237 & 2.428 \\
\hline 16. & Bumi Waras & 1.224 & 678 & 270 & 2.172 \\
\hline 17 & Way Halim & 1.162 & 682 & 266 & 2.110 \\
\hline 18. & Kedamaian & 1.209 & 729 & 284 & 2.222 \\
\hline 19. & Labuhan Ratu & 1.351 & 828 & 257 & 2.436 \\
\hline \multirow[t]{2}{*}{20.} & Langkapura & 1.162 & $\begin{array}{l}020 \\
719\end{array}$ & 261 & 2.142 \\
\hline & Jumlah & 25.385 & 15.505 & 5.434 & \multirow[t]{2}{*}{46.324} \\
\hline \multicolumn{2}{|c|}{$\begin{array}{l}\text { Jumlah Usaha Mikro dan } \\
\text { Kecil }\end{array}$} & \multicolumn{2}{|c|}{40.890} & & \\
\hline
\end{tabular}

Sumber: Diskopukm kota Bandar Lampung, 2018.

Berdasarkan tabel 1 terlihat bahwa jumlah usaha mikro di kecamatan Kedamaian sebesar 988 unit, jumlah usaha kecil sebesar 716 unit dan usaha menengah sebesar 278 unit. Sedangkan jumlah usaha mikro ditahun 2018 naik menjadi 1.209 unit, usaha kecil dan menengah mengalami peningkatan namun tidak signifikan masing-masing hanya sebesar 13 unit dan 6 unit. Hal ini terlihat jelas bahwa usaha mikro di daerah tersebut mengalami kemajuan yang pesat. Sehingga, jika usaha mikro ini dikembangkan secara baik maka diharapkan akan mengalami peningkatan. Permasalahan utama yang terjadi pada pelaku mikro di kedua daerah tersebut yaitu pemasaran yang masih manual, masih kurangnya pengetahuan akan teknik pemasaran yang baik serta penyusunan keuangan yang baik 
menjadi kendala tersendiri bagi mereka untuk bisa maju padahal teknologi tidak bisa dilepaskan dari kehidupan bisnis.

Teknologi memberikan peranan yang cukup vital dalam kegiatan bisnis (Lestari, 2020; Purwanto \& Veranita, 2018; Yudaninggar, 2019; Satria, 2019). Hampir seluruh pelaku bisnis menggunaan teknologi baik dalam proses produksi maupun pemasaran barang. Salah satu bentuk teknologi yang digunakan dalam kegiatan bisnis yaitu Smart phone. Smart phone atau yang lebih dikenal memiliki fungsi sebagai alat komunikasi juga dapat berfungsi sebagai alat media penghasil gambar atau photo yang mampu menarik membantu penjual dalam memasarkan produknya. Disisi lain kebermanfaatan smart phone sebagai media kamera untuk menghasilkan gambar yang menarik belum sepenuhnya dimanfaatkan oleh warga setempat khususnya di kelurahan Tanjung Raya RT 015. Hal ini disebabkan masih lemahnya keterampilan dn pengetahuan mereka dalam melakukan teknik photographi yang tepat. Selain itu penyusunan laporan keuangan yang benar dan tepat juga turut membantu para pelaku UMKM mendapatkan modal tambahan untuk mengembangkan usaha mereka. Oleh karena itu perlunya pelatihan keterampilan basic photography dan penyusunan laporan keuangan untuk memperluas pemasaran serta memperoleh tambahan dana dari pemerintah.

\section{Solusi}

Berdasarkan latar belakang yang telah dijelaskan pada bab sebelumnya maka dapat ditraik kesimpulan yaitu kelemahan dibidang promosi dan manajemen keuangan. Sehingga untuk mengatasi masalah tersebut langkah-langkah yang akan diambil yaitu:

\section{Masalah promosi}

Promosi merupakan hal yang penting dalam dunia usaha karena promosi merupakan salah satu alat komunikasi bisnis. Dalam promosi ini penjual dapat memberikan pengetahuan akan keunggulan produk kepada pelanggan atau memberikan pengetahuan akan produk kepada pembeli potensial. Promosi yang baik dapat dilakukan dengan melakukan riset dan analisis terhadap pasar (Tayebi, 2013). Maka solusi yang akan diberikan untuk permasalahan yang pertama yaitu pelatihan basic photography, photographi merupakan salah satu alat yang baik dalam mempromosikan sebuah produk. Kemasan photo yang menarik akan menimbulkan keinginan pembeli potensial untuk memperhatikan detail produk tersebut sehingga dapat menarik minat pembeli. Terlebih sekarang ini banyak pelaku usaha yang menggunakan media internet untuk menjual produknya, sehingga kemasan photo yang baik sangat dibutuhkan dalam pelatihan ini. Dalam pelatihan ini tim PkMP akan melibatkan narasumber yang ahli dibidangnya. Selain itu solusi yang kedua yaitu teknik pemasaran melalui online, pada tahap ini pembeli akan diajarkan melakukan penjualan atau promosi barang melalui instagram dan facebook sebelum akhirnya akan masuk ke metode penjualan online lainnya. Luaran dari pelatihan ini yaitu berupa photo produk dan akun penjualan online.

\section{Masalah manajemen keuangan}

Untuk mengatasi masalah ini maka solusi yang akan diberikan akan peningkatan pengetahuan dan keterampilan dalam menyusun laporan keuangan yang baik. Laporan keuangan adalah hasil dari proses akuntansi dan merupakan informasi historis (Sadeli, 2002; Agustina, dkk, 2019; Kurniawansyah, 2016; Manoppo \& Pelleng, 2018). Akuntansi adalah proses pengidentifikasian, mengukur dan melaporkan informasi ekonomi untuk membuat pertimbangan dan mengambil keputusan yang tepat bagi pemakai informasi tersebut (Sudiana,dkk, 2019; Anggraeny, dkk, 2018; Dewi, dkk, 2017; Shonhadji, dkk, 2017).

Tujuan laporan keuangan menurut Sadeli (2002) adalah

1. Menyediakan informasi yang dapat diandalkan tentang kekayaan dan kewajiban.

2. Menyajikan informasi yang dapat diandalkan tetang perubahan kekayaan bersih perusahaan sebagai tentang perubahan kekayaan bersih perusahaan sebagai hasil dari kegiatan usaha.

3. menyajikan informasi yang dapat diandalkan tentang perubahan kekayaan bersih yang bukan berasal dari kegiatan usaha.

4. Menyajikan informasi yang dapat membantu para pemakai dalam menaksir kemampuan perusahaan memperoleh laba. 
5. Menyajikan informasi lain yang sesuai atau relevan dengan keperluan para pemiliknya.

Berdasarkan definisi dan tujuan dari laporan keuangan diatas, maka disimpulkan bahwa laporan keuangan adalah suatu bentuk pertanggungjawaban keuangan kepada pihak-pihak tertentu yang dituangkan dalam bentuk laporan tertulis yang mampu memberikan informasi kepada pihak-pihak yang berkepentingan dalam rangka untuk pengambilan keputusan.

Pada tahap ini peserta akan dikenalkan dengan proses siklus akuntansi dan menganalisa sekilas laporan keuangan. Sehingga diharapkan peserta akan menerapkan ilmu tersebut dan dapat mengatur keuangan dengan baik sehingga dapat memperbesar modal usaha dan meningkatkan pendapatan. Luaran dari produk ini yaitu penjurnalan dan laporan keuangan sederhana.

\section{Tujuan Kegiatan}

Tujuan dari kegiatan pengabdian ini yaitu antara lain:

1. Meningkatkan keterampilan pelaku usaha mikro dibidang photography akan produk yang akan dijual.

2. Meningkatkan keterampilan pelaku usaha mikro dibidang penyusunan laporan keuangan.

\section{Manfaat kegiatan}

Adapun manfaat yang dihasilkan dari kegiatan ini yaitu:

1. Dapat meningkatkan keterampilan soft skill dan hard skill peserta.

2. Dapat meningkatkan pendapatan peserta.

\section{Metode pelaksanaan}

\section{Metode}

Pengabdian ini akan dilakukan dengan metode yang akan digunakan dalam kegiatan pengabdian ini yaitu antara lain:

\section{Sosialisasi}

Pada tahapan ini tim akan melakukan sosialisasi kepada tokoh masyarakat setempat mengenai program yang akan diberikan. Selain itu, tim akan meminta arahan tokoh setempat untuk menunjuk peserta yang akan menjadi target dari kegiatan pengabdian ini dan meminta tokoh setempat atau mitra untuk berkontribusi berupa penyediaan lokasi serta fasilitas berupa speaker active dan mikrofon.

\section{Perancangan sistem yang solutif}

Pada tahapan ini tim akan berkoordinasi untuk merancang sistem yang baik dan solutif untuk memecahkan masalah mitra berdasarkan kondisi lapangan yang sesungguhnya.

Bagan Arus 1.

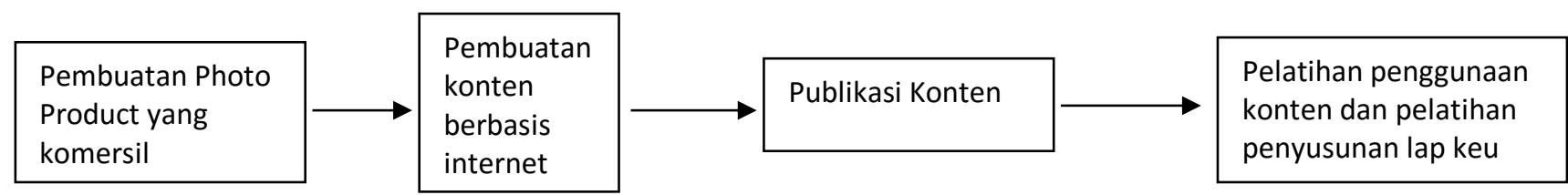

Gambar 1.

\section{Pelatihan}

Pada tahapan ini peserta akan diberikan pelatihan berupa photography yang akan diberikan oleh narasumber luar serta pelatihan penyusunan laporan keuangan yang akan diberikan oleh tim. Dalam kegiatan ini peserta diharapkan membawa Hp sebagai alat untuk kegiatan Photographi.

\section{Evaluasi}

Pelaksanaan akan dievaluasi dengan ketercapaian target luaran yang telah dipaparkan pada Tabel 1. Teknologi tepat guna atau sistem yang akan dibuat, bisa dievaluasi dari berjalannya sistem yang telah dibuat. Evaluasi selanjutnya adalah tentang publikasi ilmiah di jurnal nasional yang terakreditasi atau memiliki ISSN. Desain komersialisasi produk dapat dilihat pada draf kemasan produk baru yang telah 
dibuat oleh pengusul. Dengan ini, diharapkan mitra dapat berkembang lebih maju sesuai dengan target yang ingin dicapai.

\section{Hasil dan pembahasan}

Photografi dan penyusunan laporan keuangan merupakan keahlian yang mampu mendukung kemajuan bisnis UMKM. Penyajian produk di dunia maya yang menarik mampu menjadi salah satu strategi bisnis untuk menarik pembeli dalam melakukan transaksi jual beli. Selain itu penyajian laporan keuangan terkadang menjadi kendala tersendiri bagi pelaku UMKM disebabkan karena masih kurangnya pengetahuan dan pemahaman pelaku UMKM dalam menyusun laporan keuangan. Oleh karena itu, tim beserta narasumber dari luar bekerja sama untuk memberikan pelatihan yang mampu menjawab kebutuhan partisipan kegiatan pengabdian.

Kegiatan pengabdian ini semula direncanakan berlangsung 3 hari namun karena kondisi wabah covid, kegiatan pelatihan ini hanya berlangsung satu hari. Kegiatan ini dihadiri oleh 14 partisipan dengan beragam kegiatan usaha yang mayoritas yaitu bergerak dalam industry makanan dan minuman. Agar kegiatan ini dapatberjalan dengan lancar maka tim bekerjasama dengan pemilik yayasan Akper Bunda Delima untuk peminjaman fasilitas ruangan dan peralatan. Selain itu, tim juga bekerjasama dengan ketua RT 015 kelurahan Tanjung Raya untuk meminta izin berlangsung nya kegiatan tersebut dan juga mengundang para pelaku usaha kecil mikro maupun menengah untuk dapat hadir dalam kegiatan tersebut. Meskipun suasan dalam kondisi covid 19 namun tim tetap menerapkan prosedur covid 19 seperti pengunaan masker mencuci tangan, pengukuran suhu tubuh, serta penyemprotan hand sanitizer pada peserta kegiatan serta narasumber untuk mencegah kemungkinan tertularnya virus korona.

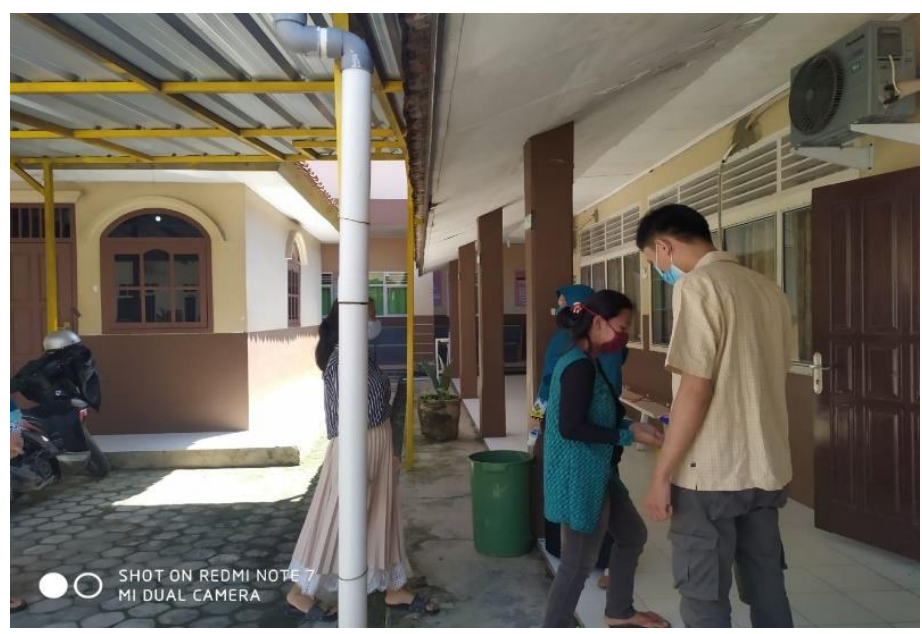

Gambar 2. Penyemprotan desinfektan

Kegiatan ini terbagi menjadi 3 bagian yaitu bagian pembuka, bagian inti, dan bagian penutup. Pada bagian pembuka, kegiatan ini dilakukan dengan melakukan uji pretest terlebih dahulu. Tujuan dari pemberian uji pre test ini yaitu untuk mengukur tingkat pemahaman dan pengetahuan peserta sebelum uji dilakukan. Pengujian dilakukan dengan memberikan pertanyaan sejumlah 10 pertanyaan dengan cara dibacakan di forum dengan model jawaban ya atau tidak atau dummy 1 dan 0 . Berikut ini adalah format pertanyaan yang diberikan:

Tabel 3. Indikator pada pertanyaan pre test

\begin{tabular}{|l|l|c|c|c|}
\hline No & Indikator/Tujuan Instruksional Khusus (TIK) & Butir Soal & Jumlah Soal & \% \\
\hline 1 & $\begin{array}{l}\text { Pengetahuan teknik mengambil gambar yang baik } \\
\text { dengan menggunakan Hp }\end{array}$ & 1 & 1 & 10 \\
\hline 2 & $\begin{array}{l}\text { Pengetahuan tentang teknik pencahayaan yang } \\
\text { baik }\end{array}$ & 2 & 1 & 10 \\
\hline
\end{tabular}




\begin{tabular}{|l|l|c|c|l|}
\hline 3 & $\begin{array}{l}\text { Pengetahuan tentang penyajian produk agar } \\
\text { menghasilkan barang yang menarik }\end{array}$ & 3 & 1 & 10 \\
\hline 4 & Pengetahuan tentang jenis-jenis laporan keuangan & 4 & 1 & 10 \\
\hline 5 & Pengetahuan tentang jurnal umum & 5 & 1 & 10 \\
\hline 6 & Pengetahuan tentang poting ke buku besar & 6 & 1 & 10 \\
\hline 7 & Pengetahuan tentang siklus akuntansi & 7 & 1 & 10 \\
\hline 8 & $\begin{array}{l}\text { Pengetahuan tentang penyusunan laporan } \\
\text { keuangan posisi keuangan }\end{array}$ & 8 & 1 & 10 \\
\hline 9 & Pengetahuan tentang penyusunan laba rugi & 9 & 1 & 10 \\
\hline 10 & Pengetahuan tentang penyusunan arus kas & 10 & 1 & 10 \\
\hline
\end{tabular}

Berdasarkan hasil uji pre test diperoleh hasil bahwa 75 persen tidak mengetahui mengenai teknik penyusunan laporan keuangan dan teknik photography yang baik dan benar. Berikut jumlah jawaban yang dihasilkan:

Tabel 4. Hasil Uji Pre test

\begin{tabular}{|l|l|c|c|c|}
\hline No & Indikator/Tujuan Instruksional Khusus (TIK) & Butir Soal & $\begin{array}{c}\text { Jumlah } \\
\text { Jawaban } \\
\text { yang benar }\end{array}$ & $\%$ \\
\hline 1 & $\begin{array}{l}\text { Pengetahuan teknik mengambil gambar yang baik } \\
\text { dengan menggunakan Hp }\end{array}$ & 1 & 6 & 42,86 \\
\hline 2 & $\begin{array}{l}\text { Pengetahuan tentang teknik pencahayaan yang } \\
\text { baik }\end{array}$ & 2 & 5 & 35,71 \\
\hline 3 & $\begin{array}{l}\text { Pengetahuan tentang penyajian produk agar } \\
\text { menghasilkan barang yang menarik }\end{array}$ & 3 & 8 & 57,14 \\
\hline 4 & Pengetahuan tentang jenis-jenis laporan keuangan & 4 & 2 & 14,29 \\
\hline 5 & Pengetahuan tentang jurnal umum & 5 & 0 & 0 \\
\hline 6 & Pengetahuan tentang poting ke buku besar & 6 & 0 & 0 \\
\hline 7 & Pengetahuan tentang siklus akuntansi & 7 & 0 & 0 \\
\hline 8 & $\begin{array}{l}\text { Pengetahuan tentang penyusunan laporan } \\
\text { keuangan posisi keuangan }\end{array}$ & 8 & 0 & 0 \\
\hline 9 & Pengetahuan tentang penyusunan laba rugi & 9 & 14 & 100 \\
\hline 10 & Pengetahuan tentang penyusunan arus kas & 10 & 10 & 0 \\
\hline
\end{tabular}

Setelah uji pre test dilakukan maka tahapan selanjutnya yang dilakukan yaitu memberikan pelatihan teknik photographi yang kemudian dilanjutkan dengan pelatihan penyusunan laporan keuangan. Kegiatan pelatihan photography peserta diminta untuk mengatur setingan hand phone peserta agar dapat mengikuti tahapan-tahapan yang diberikan oleh narasumber.

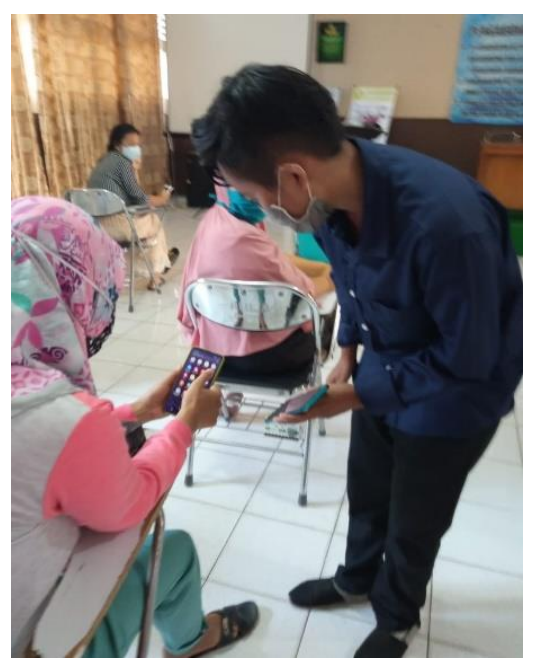




\section{Gambar 3. Pengaturan kamera HP}

Setelah itu maka peserta ditunjukkan oleh narasumber mengenai teknik pencahayaan yang baik agar menghasilkan gambar yang menarik. Peralatan yang butuhkan yaitu lampu emergency, karton putih, kardus yang sudah dibuat membentuk ruangan dimensi yang telah dilapisi karton putih dan kertas minyak warna putih. Setelah itu peserta akan diberikan contoh teknik pengambilan yang baik oleh narasumber sebelum akhirnya peserta diminta untuk mempraktekkan cara pengambilan gambar.

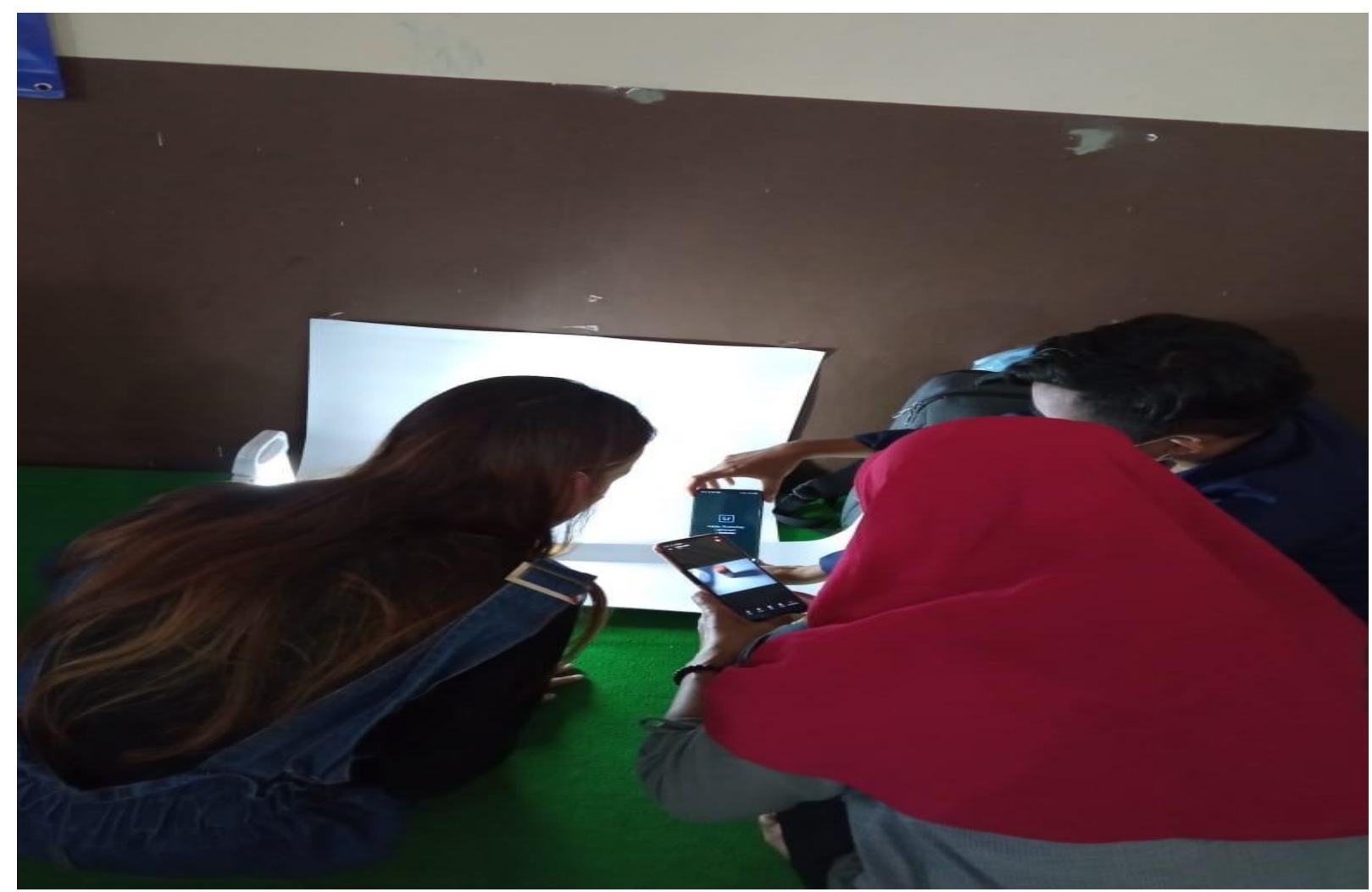

Gambar 4. Pelatihan pengambilan gambar oleh peserta

Materi inti yang kedua setelah pelatihan mengenai teknik-teknik photograpgy dilakukan yaitu memberikan pemaparan mengenai penyusunan laporan keuangan yang dimulai dari penjelasan mengenai jenis-jenis laporan keuangan, mandaat laporan keuangan, jurnal umum, posting ke buku besar hingga penyusunan laporan keuangan. Pada sesi ke dua ini terlihat bahwa masih kurangnya pemahaman peserta sehingga terlihat masih sulitnya peserta dalam menyusun laporan keuangan meskipun peserta mengikuti dengan antusias. 


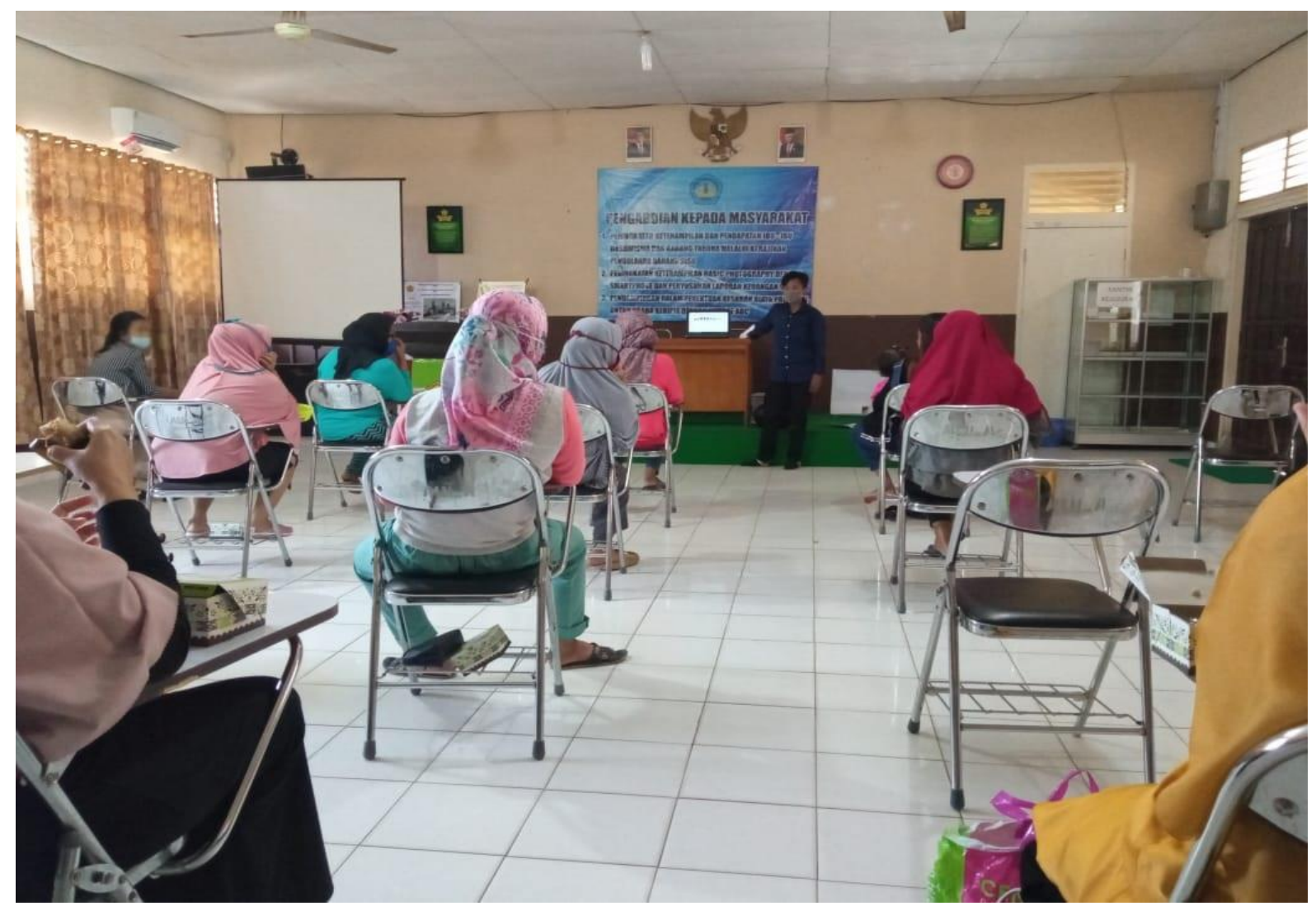

Gambar 5. Pemaparan materi penyusunan laporan keuangan

Tahapan yang ketiga yang dilakukan setelah kegiatan inti yaitu melakukan uji post test. Uji ini bertujuan untuk mengetahui tingkat daya serap peserta terhadap ilmu yang telah diberikan. Butir pertanyaan yang digunakan dalam uji post test ini yaitu masih sama dengan butir pertanyaan yang diberikan pada uji pre test dengan jumlah soal butir pertanyaan yang sama banyak yaitu 10 soal. Berikut ini adalah tabel hasil yang diperoleh dari uji post test yang telah dilakukan.

Tabel 5. Hasil post test

\begin{tabular}{|l|l|c|c|c|}
\hline No & Indikator/Tujuan Instruksional Khusus (TIK) & Butir Soal & $\begin{array}{c}\text { Jumlah } \\
\text { Jawaban } \\
\text { yang benar }\end{array}$ & \% \\
\hline 1 & $\begin{array}{l}\text { Pengetahuan teknik mengambil gambar yang baik } \\
\text { dengan menggunakan Hp }\end{array}$ & 1 & 10 & 71,43 \\
\hline 2 & $\begin{array}{l}\text { Pengetahuan tentang teknik pencahayaan yang } \\
\text { baik }\end{array}$ & 2 & 10 & 71,43 \\
\hline 3 & $\begin{array}{l}\text { Pengetahuan tentang penyajian produk agar } \\
\text { menghasilkan barang yang menarik }\end{array}$ & 3 & 14 & 100 \\
\hline 4 & Pengetahuan tentang jenis-jenis laporan keuangan & 4 & 6 & 42,86 \\
\hline 5 & Pengetahuan tentang jurnal umum & 5 & 6 & 42,86 \\
\hline 6 & Pengetahuan tentang poting ke buku besar & 6 & 6 & 42,86 \\
\hline 7 & Pengetahuan tentang siklus akuntansi & 7 & 6 & 42,86 \\
\hline 8 & $\begin{array}{l}\text { Pengetahuan tentang penyusunan laporan } \\
\text { keuangan posisi keuangan }\end{array}$ & 8 & 4 & 28,57 \\
\hline 9 & Pengetahuan tentang penyusunan laba rugi & 9 & 14 & 100 \\
\hline 10 & Pengetahuan tentang penyusunan arus kas & 10 & 10 & 0 \\
\hline
\end{tabular}


Berdasarkan data perhitungan diatas maka diperoleh hasil secara keseluruhan 40 persen memahami atau dapat menyerap ilmu yang telah diberikan. Hasil ini meski masih terbilang kecil namun jika dibandingkan dengan jumlah pre test terlihat terjadi peningkatan sebesar $15 \%$. Dari jumlah total tersebut jika dibagi kembali maka terlihat bahwa 81 persen peserta mampu menyerap teknik photography yang telah diberikan sedangkan pada tingkat pemahaman akan penyusunan laporan keuangan diperoleh hasil sebagai berikut $22,45 \%$ yang memahami teknik penyusunan laporan keuangan.

\section{Faktor pendukung}

Kegiatan PkM ini berjalan dengan lancar karena adanya respon positif dan dukungan dari RT setempat dan ketua yayasan Akper Bunda Delima. Antusias peserta untuk menyimak materi yang diberikan tentu saja menjadi energy tersendiri bagi keberlangsungan acara tersebut. Antusias peserta terlihat dari peran serta aktif pada saat sesi diskusi dan juga pemotretan produk.

\section{Faktor penghambat}

Suasana covid 19 tentu saja ikut mempengaruhi keberlangsungan kegiatan PkM ini. Acara yang semula direncanakan menjadi 3 hari namun harus dipadatkan menjadi satu hari mengingat suasana covid. Selain itu, tingkat kemampuan yang berbeda-beda serta latar belakang pendidikan yang berbeda tentu saja menjadi hambatan tersendiri bagi peserta dalam menyerap ilmu mengenai akuntansi.

\section{Kesimpulan dan saran Kesimpulan}

Kegiatan PkM ini dapat memberikan dampak yang positif bagi keberlangsungan usaha atau bisnis peserta. Hal ini ditenggarai karena peserta telah dibekali ilmu pengetahuan dan keterampilan mengenai teknik photography serta penyusunan laporan keuangan yang berguna bagi peserta untuk mengembangkan usahanya juga untuk memperoleh bantuan dana. Selain itu antusias peserta yang baik tentu saja menjadi signal tersendiri bahwasannya pesesaha rta haus akan ilmu pengetahuan yang berguna bagi kemajuan usaha mereka.

\section{Saran}

Berdasarkan faktor penghambat yang telah diuraikan pada halaman sebelumnya maka tim penulis menyarakan sebaiknya pelatihan ini dilakukan dalam jangka waktu yang panjang dan memberikan pelatihan berdasarkan kelompok tingkat kemampuan yang sama, sehingga dengan demikian ilmu yang diberikan yang bersifat kompetensi akademik dapat terserap dengan baik.

\section{Ucapan terima kasih}

Ucapan terima kasih penulis sampaikan kepada Ibu Ade widiyanti selaku Ketua yayasan Akper Bunda Delima yang telah membantu menyediakan fasilitas sarana dan prasarana serta kepada bapak Syarifudin selaku ketua RT yang telah membantu terlaksananya kegiatan PkM serta bapak Babinsa.

\section{Referensi}

Anggraeny., Khudori, Ahmad., \& Fikria, Ainun. (2018). Pelatihan Penyusunan Laporan Keuangan Dalam Lingkup Yayasan Pendidikan Dan Pondok Pesantren Subulul Huda Kembang Sawit Dikemas; Jurnal Pengabdian Kepada Masyarakat, 2(1).

Badan Pusat Statistik. (2016). Pertumbuhan Ekonomi Indonesia Tahun 2015. http://www.bps.go.id. Diakses pada 4 Februari 2018.

Dewi, Ni Komang., Herawati, Nyoman., \& Atmadja, Anantawikrama. (2017). Penyusunan Laporan Keuangan Sesuai Dengan Standar Akuntansi Keuangan Entitas Mikro, Kecil, dan Menengah (SAK EMKM) Pada Usaha Ternak Ayam Boiler (Study Kasus Pada Usaha I Wayan Sudiarsa Desa Pejahan Kecamatan Pupuan Kabupaten Tabanan). Jurnal Ilmiah Akuntansi UNDIKSHA, $8(2)$.

Dinas Koperasi dan UMKM. (2018). Data-UMKM-Bandar Lampung.pdf. Diskopukm.bandarlampungkota.go.id. Diakses pada 21 Februari 2020. 
Dinas koperasi, perindustrian, dan perdagangan. (2014). Data UMKM per Kecamatan Kota Bandar Lampung tahun 2014. Lakipdiskoperindag.bandarlampung kota.go.id. Diakses 21 Februari 2016.

Kurniawansyah. (2016). Penerapan Pencatatan Akuntansi dan Penyusunan Laporan Keuangan Berdasarkan SAK ETAP Pada UMKM Desa Gembongsari Kecamatan Kalipuro Kabupaten Banyuwangi. Dinamika Global: Rebranding Keunggulan Kompetitif Berbasis Kearifan Lokal.

Lestari, Putu. (2020). Pelatihan Teknik Fotografi Menggunakan Smart Phone Untuk Meningkatkan Nilai Produk Hasil Kerajinan Tangan Di Yayasan Kasih Peduli Anak Kota Denpasar. Jurnal Lentera Widya, 1(2).

Manoppo \& Pelleng. (2018). Pelatihan Penyusunan Laporan Keuangan Dengan Teknik Pembukuan Sederhana Bagi Pelaku Usaha UMKM Di Kecamatan Malalayang Kota Manado Provinsi Sulawesi Utara. Jurnal Administrasi Bisnis, 7(2).

Purwanto, Yudhy \& Veranita, Mira. (2018). Pelatihan Fotografi Dasar Bagi Pelaku Usaha Kecil dan Menengah (UMK) Kecamatan Lengkong Kota Bandung. Jurnal Darma Bhakti STIE Ekuitas, 2(2).

Sadeli, Lili. M. (2002). Dasar-dasar Akuntansi. Jakarta: Bumi Aksara.

Satria. (2019). Peningkatan Kemampuan Videografi dan Mobile Editing Video Menggunakan Smartphone Pada Organisasi Kepemudaan Daerah. Prosiding Seminar Hasil Pengabdian Masyarakat.

Shonhadji., Aghe., Djuwito. (2017). Penerapan Penyusunan Laporan Keuangan Pada Usaha Kecil Menengah Berdasarkan SAK EMKM Di Surabaya. Prosiding Seminar Nasionala Hasil Pengabdian Masyarakat, 1(1).

Sudiana., Wulandari., Padnyawati., Putra, I Putu., \& Muliati. (2019). Penyuluhan Teknik Pemasaran dan Pelatihan Penyusunan Laporan Keuangan Pada Kelompok Home Industri Kacang Kapri di Banjar Dinas Pesangkan Anyar Kecamatan Selat Karangasem. Jurnal Sewaka Bhakti, 2(1).

Tayebi, A. (2013). Planning activism: Using Social Media to claim marginalized citizens' right to the city. Cities Journal, 32, 88-93.

Worldbank. (2005). Mendukung Usaha Kecil dan Menengah. http:// siteresources.worldbank.org. Diakses pada 2 Februari 2018.

Yudaninggar, Kartikasari. (2019). Pelatihan Digital Marketing Dalam Rangka Peningkatan Pemasaran Kelompok Batik Sojiwan. Prosiding Seminar Hasil Pengabdian Masyarakat. 